CERE Working Paper, 2012:2

\title{
Command-and-Control Revisited: Environmental Compliance and Innovation in Swedish Industry 1970-1990
}

Ann-Kristin Bergquist ${ }^{1}$, Kristina Söderholm ${ }^{2}$, Hanna Kinneryd ${ }^{2}$, Magnus Lindmark ${ }^{1}$ and Patrick Söderholm²

${ }^{1}$ Department of Economic History, Umeå University

${ }^{2}$ Division of Social Sciences, Luleå University of Technology

The Centre for Environmental and Resource Economics (CERE) is an inter-disciplinary and inter-university research centre at the Umeå Campus: Umeå University and the Swedish University of Agricultural Sciences. The main objectives with the Centre are to tie together research groups at the different departments and universities; provide seminars and workshops within the field of environmental \& resource economics and management; and constitute a platform for a creative and strong research environment within the field.

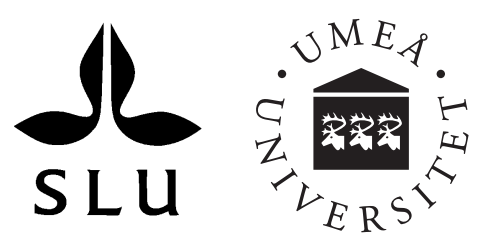




\title{
Command-and-Control Revisited: Environmental Compliance and Innovation in Swedish Industry 1970-1990*
}

\author{
ANN-KRISTIN BERGQUIST ${ }^{\mathrm{a}}$, KRISTINA SÖDERHOLM ${ }^{\mathrm{b}}$, HANNA KINNERYD ${ }^{\mathrm{b}}$, \\ MAGNUS LINDMARK ${ }^{\mathrm{a}}$, and PATRIK SÖDERHOLM ${ }^{\mathrm{b}} *$ \\ ${ }^{a}$ Department of Economic History \\ Umeå University \\ 90187 Umeå \\ Sweden \\ ${ }^{\mathrm{b}}$ Division of Social Science \\ Luleå University of Technology \\ 97187 Luleå \\ Sweden
}

Corresponding author: patrik.soderholm@ltu.se

\begin{abstract}
This paper addresses the issue of environmental policy instrument choice for achieving deep emissions reductions in the industrial sector. Specifically, it provides: (a) a theoretical review of the conditions under which performance standards can provide efficient incentives for environmental compliance and innovation; and (b) an analysis of the design and the outcomes of the standards-based regulation of industrial pollutants in Sweden during the period 19701990. The empirical findings suggest that the Swedish regulatory approach comprised many key elements of an efficient policy-induced transition towards radically lower emissions in the metal smelting and pulp and paper industries. The regulation relied heavily on performance standards, thus granting flexibility to firms in terms of selecting the appropriate compliance measures, and the standards were implemented in combination with extended probation periods. R\&D projects and the new knowledge that was advanced incrementally in interaction between the company, the environmental authorities and the research institutions provided a direct catalyst to the regulatory process. As such the Swedish regulatory approach provided scope for creative solutions, environmental innovation, and permitted the affected firms to coordinate pollution prevention measures with productive investments.
\end{abstract}

Key words: industry; pollution control; command-and-control policy; innovation; Sweden.

\footnotetext{
* Financial support from the Swedish Energy Agency, the Ragnar Söderberg Foundation and the Swedish Research Council Formas is gratefully acknowledged. Any remaining errors reside solely with the authors.
} 


\section{Introduction}

This paper addresses the issue of environmental policy instrument choice for achieving deep emissions reductions in the industrial sector. In the environmental economics literature a lot of attention has been paid to the efficiency aspects of different types of policy instruments, e.g., market-based policy instruments such as taxes and tradable emission allowances as well as policies that rely on either performance or technology standards (Copper and Oates, 1992). This research strand emphasizes analyzing the value of the expected environmental benefits and the costs at which any improvements in environmental quality can be achieved, and it also highlights the innovation-promoting impacts of different policies (e.g., Requate, 2005).

However, less attention has been paid to the dynamics of the policy compliance process, not the least in cases where governments face the challenge of imposing an emission reduction target for the future that cannot be met by employing currently existing ('off-the-shelf') technologies (Sandén and Azar, 2005; Nentjes et al., 2007). In this policy setting a number of additional policy criteria become important. It may first be noted that the pollution control policy needs to maintain strong, continuous incentives for emission reductions while at the same time taking into account the risk of excessive compliance costs for those affected by the policy. This is a particular concern in those industrial sectors that compete in global markets, and where there thus may exist a clear trade-off between stringent environmental policies on the one hand and competitiveness on the other (Jaffe et al., 1995).

Moreover, policy instruments that stimulate innovation and that permit flexibility over time in identifying, developing and demonstrating new technology will be of central interest in the transition towards deep emission reductions. Sartorius and Zundel (2005) stress that the regulatory 'time-strategy', e.g., extended compliance and trial periods, constitutes an important design issue in influencing the innovation-promoting elements of environmental policy. Earlier theoretical contributions to the environmental economics literature typically conclude that market-based instruments provide stronger incentives for environmental innovation than, for instance, performance standards (e.g., Milliman and Prince, 1989). However, empirical studies that take into account also the presence of specific policy designs, uncertainty, time strategies etc., suggest that there is no single best policy instrument to foster innovation in the environmental field (e.g., Ashford et al., 1985; Taylor et al., 2005; Kemp and Pontoglio, 2011). Additional theoretical and empirical research is therefore needed to explore under which conditions different policy instruments can contribute to environmental innovation and an efficient phase-out of emissions in important sectors of economy.

The objectives of this paper are to: (a) provide a theoretical review and discussion of the conditions under which performance standards, i.e., individual emission limits for stationary industrial plants, can provide efficient incentives for deep emission reductions; and (b) analyze the design and the outcomes of the environmental regulation of Swedish industry during the period 1970-1990.

During this period the emissions of a large number of hazardous substances (e.g., sulphur dioxide, COD, heavy metals etc.) decreased significantly in Swedish industry. The Swedish regulatory approach relied heavily on the use of performance standards, a long-term strategy on environmental innovation, as well as on close firm-regulator negotia-tions making use of 
both decentralized knowledge and jointly funded research programs. The Swedish case is interesting not only due to the strong environmental performance (e.g., Boyd, 2003), but also since Sweden adopted a slower but at the same time more cooperative and long-term pollution control strategy compared to, for instance, USA and Canada (e.g., Lundqvist, 1980; Jänicke, 1992; Lindmark and Bergquist, 2008) (see also section 3.2). This, we argue, facilitated the integration of new environmental technology in long-term production process investments. In the paper we analyze the environmental adaptation of one hotspot metal smelter in northern Sweden and of the country's pulp and paper industry.

Kemp and Pontoglio (2011) argue that the case study approach towards investigating the compliance and innovation impacts of existing environmental regulations is a useful complement to econometric and survey-based evidence. Case studies can reveal how choices are made in situations of uncertainty and mutual influence between the affected firms as well as between the firms and the regulator. It is important to contextualize the process of policy compliance and technical change; this process takes place within specific actor networks, is shaped by the available technological knowledge (in firms and research institutes) and it is typically informed by managerial and engineering notions of what is technologically feasible and economically worthwhile to do. For this reason case studies permit a more in-depth analysis of how different policies interact in practice as well as how specific policy features have shaped choices of compliance and investments in environmental innovation.

The existing case study literature comprises a number of interesting studies on industrial pollution control, including the seminal study by Ashford et al. (1985) on ten regulatory cases in USA. Yarime (2007) addresses the issue of mercury control from chlor-alkali plants in Japan, stressing in particular the importance of avoiding the forcing of suboptimal technologies. A number of Finnish cases are analyzed in Mickwitz (2003), Mickwitz et al. (2008), Kivimaa and Mickwitz (2004) and Similä (2002). These studies focus on different industrial sectors in Fin-land (most notably the pulp and paper industry), and illustrate the importance of, for instance, the timing of the regulatory process in relation to innovation efforts. Another important conclusion is also that there appears to be little evidence of one policy instrument being superior than others in promoting environmental innovation; instead specific policy designs and the institutional context may matter just as much.

This paper adds to these previous case studies on the innovation impacts of environmental policy in part by addressing novel empirical experiences from Sweden. In addition, unlike most of the earlier case studies it also provides a theoretical discussion of the role of regulatory design in imposing technology-forcing standards, i.e., required emission reductions that are significantly more stringent than currently available 'off-the-shelf' technologies can offer (Nentjes et al., 2007). We contend that many of the key elements of an efficient regulationinduced transition towards radically lower emissions into water and air were prevalent in the Swedish regulatory approach, and the experiences from the two industry cases could therefore provide lessons for contemporary regulatory efforts targeting large industrial facilities.

The paper proceeds as follows. Section 2 provides an economic-theoretical discussion on efficient environmental policy instrument choice, with special emphasis on the circumstances under which performance standards could promote an efficient and a politically achievable 
deep reduction in industrial emissions. The analysis addresses both the policy impact on environmental innovation as well as the role of the policy-making process and firm-regulator interactions in the context of technological uncertainty. In section 3 we review the most important characteristics of the Swedish environmental protection system during the period 1970-1990, and briefly highlight some differences between the Swedish system and the corresponding regulatory approaches in a number of other countries.

Sections 4 and 5 provide empirical analyses of the nature and the outcomes of the regulation of the Rönnskär metal smelter and the pulp and paper industry in Sweden. The empirical information that forms the basis for these investigations consists of archive materials employed in two previous Ph.D. dissertations (Bergquist, 2007; Söderholm, 2005), several recent publications on green knowledge and technical progress in the Swedish pulp and paper industry (Bergquist and Söderholm, 2012, 2010; Söderholm, 2007, 2009; Söderholm and Bergquist, 2012), as well as a research report mapping a large number of pulp and paper licensing processes taking place during the period 1969-1992 (Kinneryd, 2010). Moreover, the authors have undertaken several interviews with representatives of the relevant industrial firms and research institutes as well as with government officials at the concerned authorities. ${ }^{1}$ The above material has not yet been analyzed in the context of the choice of efficient pollution control policies, but here it permits an in-depth analysis of how the regulatory process interacted with the compliance and research activities of the industry. Finally, section 6 provides a concluding discussion in which we synthesize the main findings and contrast these to the results of previous research.

\section{The Case for Command-and-Control in Environmental Regulation}

A key issue in regulating a polluting industrial plant is whether to employ price or quantity rules in controlling pollution levels, e.g., imposing a tax or charge on pollution or stipulating a quantitative (performance) standard for required emissions reductions. The former is referred to as a market-based solution while the latter signifies a command-and-control (CAC) approach. $^{2}$ Economists generally argue that the market-based approach is more efficient than CAC. Two broad sources of inefficiency of the CAC approach are frequently quoted:

\footnotetext{
${ }^{1}$ These include, for instance: (a) a personal interview with Stig Freyshuss, president of the Water Laboratory of the Forest Industry in 1958 to 1964 and of IVL in 1966 to 1982 (08.10.2009); (b) telephone interview with KarlFredrik Gustavsson, a faithful servant (deceased in 2011) of the Swedish forest industry with great interest in environmental issues (26.05.2010); (c) a personal interview with Arne Jernelöv, research leader at IVL in the 1970s (19.05.2010); (d) a personal interview with Måns Lönnroth, State Secretary at the Ministry of Environment, and CEO for the Foundation for Strategic Environmental Research (MISTRA) (26.05.2010); (e) a personal interview with Hans Norrström, ÅF-konsult (07.06.2010); and (f) a personal interview with Ulla-Britta Fahlénius, Swedish Environmental Protection Agency (09.06.2010).

${ }^{2}$ We only discuss the case of individual performance standards, which leave it to the firm to identify the relevant compliance measures and thus ignore the case of technology standards, which dictate what specific technologies or processes firms must use. By design these provide little leeway to undertake other (cost-effective) measures. We also do not discuss the case where performance standards are transformed into tradable emission allowances. Although cost-effective in theory such schemes may be difficult to implement for pollutants with strong local impacts and/or when the number of polluters are too small to constitute an efficient market (
} 
- Polluting plants typically differ in terms of their abatement costs, and firm-regulator information asymmetries are normally present. In other words, plant owners know far better than the regulator what it will cost to abate emissions (and have no incentive to reveal this information). ${ }^{3}$ For this reason it is virtually impossible for the regulator to allocate abatement efforts to the sources who find it cheapest to abate pollution.

- Although the literature shows that it is virtually impossible to present a generic ranking of different pollution control instruments with respect to their innovationstimulating impacts, it is often claimed that the market-based approach tend to perform better than CAC policies. The main reason is that in the latter case the polluter has no incentive to perform beyond the pre-determined standard, while market-based instruments induce polluters to conduct low-cost abatement beyond the current level (e.g., since this reduces tax payments).

More recent contributions to the literature show, though, that the advantages of market-based instruments over CAC do not always hold, in particular if the regulator is genuinely uncertain about firms' abatement costs (e.g., Weitzman, 1974; Stavins, 1995), and if technical innovation is deemed necessary to reach future emission reductions (e.g., Requate and Unold, 2003, Bruneau, 2004).

In this section we discuss the case of technology-forcing policies, i.e., those which aim at deep emission reductions that require a higher rate of pollution prevention than currently available 'off-the-shelf' technologies can offer (Nentjes et al., 2007). In brief, in this type of policy setting: (a) abatement cost uncertainties are prevalent; (b) this uncertainty concerns firms' decisions just as much as the regulators; and (c) the impact on technical innovation represents an important policy criteria. Moreover, in this environmental transition process it is also useful to consider the interaction between the objectives of the regulator and the profit motives of the firms. The regulator typically faces competing objectives manifested in the trade-off between environmental compliance on the one hand and the competitiveness of the industry on the other. Our review of the literature indicates that under these circumstances CAC policies may be as efficient as market-based policy instruments, and could even provide a greater spur to innovation. Next in this section we discuss the potential role for CAC policies when the regulator is uncertain about abatement costs, and finally we revert to the issue of the innovation-stimulating impacts of environmental regulation.

\subsection{Policy Instrument Choice in the Presence of Uncertain Pollution Abatement Costs}

Figure 1 builds on Weitzman (1974) and provides a simple economic model for analyzing the economic efficiency of pollution taxes and performance standards in the presence of uncertain abatement costs. An economically efficient pollution abatement level requires that the level of abatement, $A$, is at the level where the marginal abatement costs, $M C_{A}$, equals the marginal benefits of pollution abatement, $M B_{A}$ (thus corresponding to the value of the avoided environmental damages at the margin). We assume that the regulator can properly identify $M B_{A}$, but she is assumed to have incomplete knowledge about $M C_{A}$. For this reason we

\footnotetext{
${ }^{3}$ Moreover, under the CAC approach the regulator must also use up resources to - as far as is found necessary acquire the information that polluters already possess. The fact that firms - in the presence of information asymmetries - will have an incentive to signal high abatement costs to avoid the likelihood of more stringent future regulations is sometimes referred to as the ratchet effect (e.g., Kolstad, 2000).
} 
introduce a distinction between the expected marginal cost curve, $M C_{A}^{E}$, and the true marginal abatement cost curve, $M C_{A}^{T}$. Based on these assumptions we can now identify two different situations, one in which the marginal benefit curve is fairly flat and the marginal cost curve is relatively steep (see graph (a)) and one where the opposite holds (see graph (b)). As shown by Weitzman (1974), the relative slopes of these curves will influence the expected efficiency of price- versus quantity-based policies.

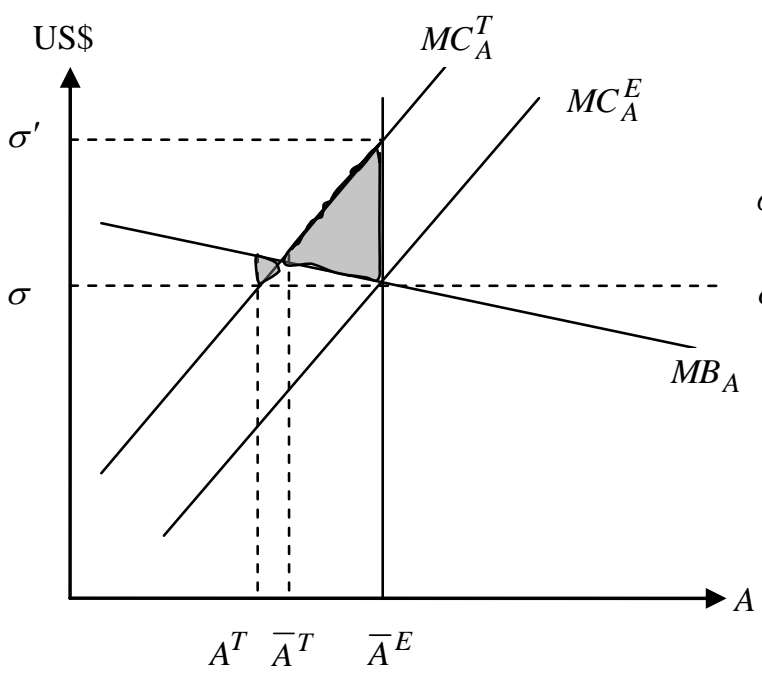

(a)

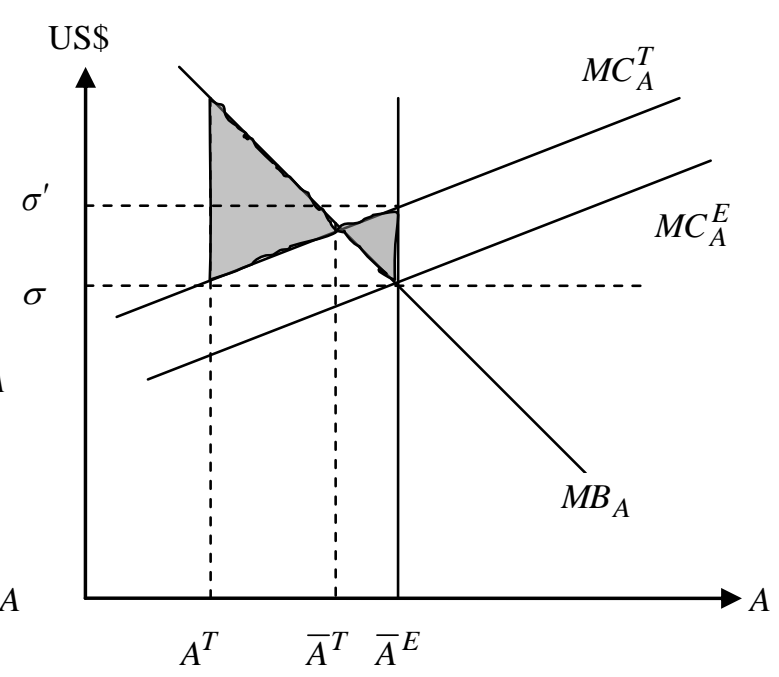

(b)

Figure 1: The Efficiency of Pollution Taxes and Performance Standards under Uncertainty

This can be illustrated by first noting that in each of the two graphs, the regulator assumes that $\bar{A}^{E}$ represents the efficient level of pollution abatement. In practice, however, the true marginal abatement costs are higher than expected, and the efficient level of $A$ is therefore lower and equals $\bar{A}^{T}$. If the regulator uses a pollution tax to achieve the $\bar{A}^{E}$ target, the tax level will bet set at $\sigma$. However, at this support level only $A^{T}$ units of abatement will be achieved. The difference between the actual and the (true) efficient abatement level leads to an efficiency loss, which equals the area represented by the left triangles in graphs (a) and (b). If instead a performance standard is implemented, this would be set at $\bar{A}^{E}$. The shadow price of abatement will equal $\sigma^{\prime}$, which is higher than the tax level that would be chosen by the regulator. The higher-than-expected marginal cost of abatement implies that actual abatement following the implementation of the performance standard will be higher than the efficient level, resulting in an efficiency loss equaling the right, shaded areas in graphs (a) and (b). The two examples in Figure 1 illustrate the important result that when the regulator is uncertain about the locus of the (linear) marginal abatement cost curve $M C_{A}$, quantitative performance standards are likely to be more efficient than tax policies if (and only if) $M C_{A}$ is relatively flat as compared to the slope of the (linear) marginal benefit curve $M B_{A}$. This is the case in graph (b), while in graph (a) the situation is reversed and price-based policies will be preferred. ${ }^{4}$

\footnotetext{
${ }^{4}$ Uncertainty about the position of $M B_{A}$ will also lead to efficiency losses, but the magnitudes of these losses will typically not differ depending on the pollution control policy chosen. Thus, the choice between price- and quantity-based policy instruments is not affected by such uncertainty.
} 
The intuition behind this result is that if the slope of $M B_{A}$ is steep an increase in $M C_{A}$ will justify only a fairly small decrease in the quantity of emissions abated since the value to society of avoiding further emissions is high. Hence, in this case the performance standard that was thought efficient in the erroneous ex ante assessment will still turn out to be nearly correct. This concern is particularly important in the regulatory control of the emissions of, for instance, hazardous substances for which there may exist critical threshold levels that should not be exceeded (Söderholm and Christiernsson, 2008). Moreover, the case for a CAC policy will be further strengthened if the (uncertain) marginal cost curve is relatively flat, since in this case firms' overreaction following a tax policy will be great, thus generating either too much or too little abatement depending on the realization of the stochastic element of the model.

While the above model illustrates circumstances under which performance standards can be preferred over market-based instruments, it should however be noted that this model builds on restrictive assumptions that could be important for the central conclusions. This includes, for instance, the assumption of a tax that is both fixed and linear (e.g., Kaplow and Shavell, 2002). The strongest case for a CAC approach may exist in situations where deep emission reductions are deemed necessary, and where technological change and policy legitimacy are central concerns. The next section develops these notions.

\subsection{The CAC Approach to Achieve Deep Emission Reductions under Uncertainty}

Figure 2 builds on Nentjes et al. (2007) and illustrates a situation in which the regulator faces a deep emission reduction target, $\bar{A}$, which in turn can be motivated by perceived high marginal damages reaching a critical level unless this amount is abated. The three $M C_{A}$ curves show the marginal cost of abatement for a representative polluting firm for available ('off-theshelf') abatement technologies. The solid straight line represents the envelope of these immediately available technologies, implying thus a continuum of existing abatement technologies. The three dashed straight lines represent extrapolations of this envelope, and depict expectations about new technologies, which can only be employed following future $R \& D$ efforts. Still, whether R\&D will be successful in providing these technologies is uncertain.

The above implies that in the above setting the regulatory challenge consists of implementing a technology-forcing policy, i.e., a policy which ensures that a more ambitious emission reduction target is met than currently available technologies can offer (at a reasonable cost). Thus, in this case the regulatory instruments' innovation-promoting impacts constitute an important policy selection criterion. As was noted above, there is an extensive (theoretical) literature on the innovation and technology adoption impacts of different pollution policies. ${ }^{5}$ Overall this indicates that it is virtually impossible to present a unanimous ranking of policies with respect to their innovation-stimulating effects; there exist a number of different outcomes contingent on particular assumptions about, for instance, the degree of competition in the output market, the characteristics of the relevant environmental damages, which timing and commitment strategies are available for the regulator, uncertainty about future abatement costs etc. For our purposes we are particularly interested in the last of these assumptions.

\footnotetext{
${ }^{5}$ See Requate (2005) as well as Kemp and Pontoglio (2011) for comprehensive theoretical and empirical surveys of this literature.
} 


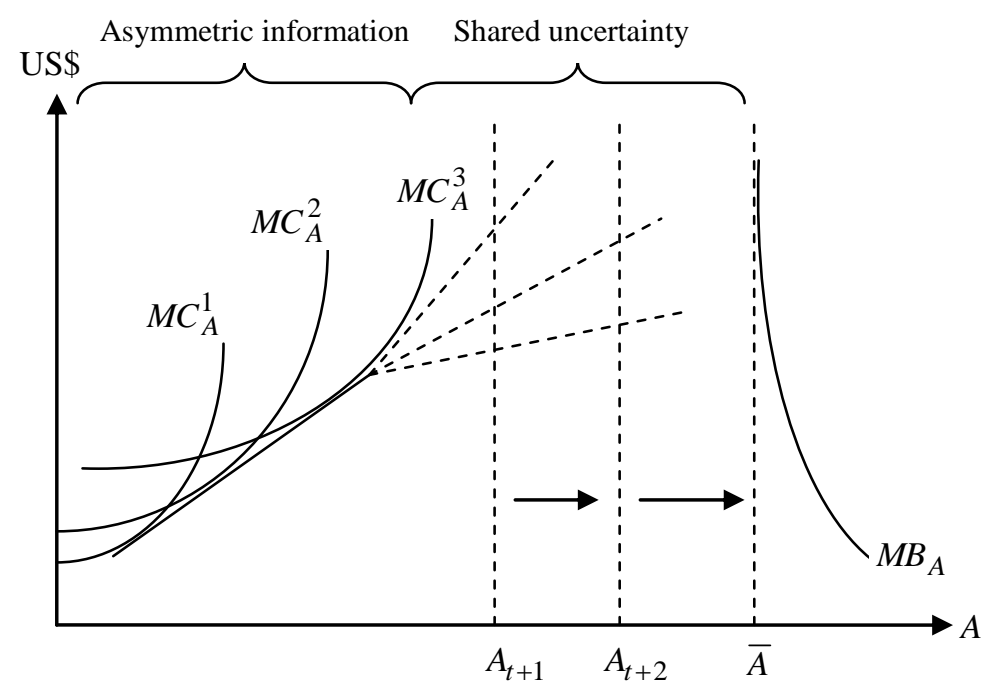

Figure 2: Marginal Abatement Costs Associated with a Transition towards a Deep Emission Cut

In the case where innovation is important and there is genuine uncertainty about future abatement costs, significant selections of the literature suggests that performance standards can be more efficient than market-based policies. Mendelsohn (1984) extends Weitzman's (1974) analysis by adding the role of endogenous technological change through R\&D. His analysis suggests that $R \& D$ can contribute with larger potential over- and undershooting with a pollution tax, thus suggesting a bias in favor of CAC policies when innovation is important. Put differently (and in the context of Figure 1), endogenous technological change implies here that the slope of marginal abatement cost curve becomes less steep. While Mendelsohn (1984) only considers the level of investment, Krysiak (2008) also addresses the role of different types of (stylized) technology choices. He concludes that different regulation approaches may (regardless of design) lead to the adoption of different technologies, and a CAC approach can induce an efficient choice of technology whereas a pollution tax cannot. Thus, in this sense the CAC policy "has a long-run advantage that is not considered in Weitzman's criterion for choosing between price- and quantity-based approaches," (Krysiak, 2008, p. 1276).

It may also be noted that while asymmetric information concerning pollution abatement costs is likely to be a significant concern in the case of existing technologies, ${ }^{6}$ it may be less prevalent in the situation where new technology needs to be tested and developed. Regulators who issue plant licenses on a case-by-case basis (and perhaps conduct own research and study visits) gain significant knowledge about novel technological solutions, information which subsequently can be utilized to put pressure on plants in future licensing processes (see also section 5). The presence of a large shared firm-regulator uncertainty as well as concentrated industrial sectors in which the heterogeneity in pollution abatement activities is low, will facilitate an efficient reliance on cooperative regulation based on negotiations and/or voluntary agreements (Glachant, 1999). Information asymmetries can however never be removed at

\footnotetext{
${ }^{6}$ The information advantage of the polluting firms will not necessarily relate so much to the characteristics of the abatement technologies as such, but rather to the ways in which this technology affects production costs at the plants once implemented in a given process.
} 
a reasonably low cost for the regulator, although the Swedish case reviewed in this paper suggests that in a situation where deep emission cuts in large stationary industrial facilities are envisaged it could be worthwhile investing heavily in regulatory (engineering) competence. Furthermore, performance standards permit flexibility for firms to identify the most costeffective compliance strategies, but improved regulatory competence is likely to improve regulators' ability to negotiate tighter standards over time.

This brings to our final issue in this theoretical discussion, namely the role of the policymaking process in the context of technological uncertainty. Nentjes et al. (2007) build on the public choice literature and outlines a model in which the regulator act as a bureaucrat with competing objectives. For our purposes the regulator can be assumed to be concerned not only by economic efficiency but she will also careful in not imposing too large economic burdens on the pollution industry due to competitiveness concerns. An important policy variable in resolving this trade-off is the allowed compliance period (Kemp, 1997). A longer compliance period implies a less rapid emission reduction, but at the same time firms have time to reduce uncertainty and compliance costs by engaging in R\&D and technology demonstration activities. $^{7}$ In Figure 2 this is illustrated by assuming that in time period $t$ the regulator imposes a performance standard $A_{t+1}$ that cannot be met by employing the technologies available in that period. However, firms are allowed to develop and test new technology during a probation period. With technical progress the regulator can impose stricter standards, e.g., $A_{t+2}$, but again in combination with an extended compliance period. As has been noted above, this regulatory strategy requires that the environmental authorities possess relevant information on abatement technology and its costs.

Kemp (1997) develops the model by Nentjes et al. (2007) (originally presented in Nentjes, 1988) by comparing the innovation effects of a performance standard and a pollution tax. He concludes that under most circumstances the performance standard provides stronger incentives to innovate in pollution abatement technology than does the tax. The reason has to do with the fact that under a pollution tax firms must pay for non-abated emissions, implying that the policy burden for the industry is often higher under a tax policy than under the CAC approach. For this reason the regulator (again concerned about industrial competitiveness) is likely to implement a comparatively low tax, and firms will undertake less R\&D in pollution control than in the CAC case. In other words, the extra tax costs that firms face withhold the regulator from technology-forcing that it could have undertaken if non-abated emissions had been free. Clearly, though, also this model builds on specific assumptions. Most notably, it only illustrates that pollution taxes tend to provide less of a spur to demand-driven innovation, but they are likely to increase the incentives to adopt supply-driven innovation. Specifically, the higher cost of emitting non-abated emission also encourages polluters to adopt technologies supplied by innovating suppliers without interference of the regulator.

The above theoretical discussion provides a framework within which the significant environmental adaptation of Swedish industry during the time period 1970-1990 can be comprehended. Still, while the economic approach to analyzing policy-induced environmental

\footnotetext{
${ }^{7}$ The notion that the costs of innovation can be reduced by extending the R\&D period has been illustrated in, for instance, Kamien and Schwartz (1982) and Viscusi et al. (2005). The extended period permits the firm to avoid errors in the innovation process, and to mitigate diminishing returns of additional scientific and engineering manpower.
} 
technology is strong on addressing the mechanisms through which policy results in technical change, it often fails to appreciate the dynamics of environmental adaptation and policy pathways. It is therefore important to complement this stylized representation of regulatory action with a more context-rich and explorative analysis. In the next section we present the most significant components of the Swedish approach to industrial pollution control during the time period 1970-1990, and this is also complemented by a number of selected insights from the political science literature on the general policy frameworks that have influenced environmental performance in differ-rent countries (e.g., Jänicke, 1992; Harrison, 2002). This research highlights the importance of not only specific policy instrument designs but also that of collaborative interaction and policy legitimacy. Several studies (e.g., Lundqvist, 1980) display evidence of systematic differences between the North American and the European regulatory approaches, and thus permit an international comparative perspective of the Swedish experience (see section 3.2).

\section{Industrial Pollution Regulation: Sweden in an International Context}

\subsection{The Swedish Environmental Regulatory System, 1970-1990}

The Swedish Environmental Protection Act, the very core of the environmental regulatory system in the country, was implemented in 1969. It represented the first uniform framework for regulation of emissions to air, water pollution, noise and other disturbing activities from industrial plants in Sweden (Lundgren, 1999). The Act was based on case-by-case judgments of every production unit engaged in polluting activities, and there existed thus no uniform emission standards. This implied that all firms engaged in polluting activities, including firms that planned to engage in such activities, had to have their plans for construction or alteration of plants, factories and other installations assessed according to several criteria specified in the Act. The licensing system was administrated by the Franchise Board of Environmental Protection (FBEP) (e.g., Swedish Code of Statues 1969:38; Lundqvist, 1980; Lundgren, 1999). Emission standards were negotiated with each industry, sometimes over extended periods of time, taking into account parameters such as the local environmental impact, possibilities for technological development and not the least long-term competitiveness. In other words, the FBEP could prescribe any protective measure for the polluting activity that could be reasonably demanded in the view of the criterion of "technical and economic feasibility". Failures in the licensing process meant that the activity had to be closed down and/or expansion plans be cancelled.

The individual firm had the flexibility to choose, develop and test technology suitable for its production processes in order to find cost effective measures to reach stipulated emission level values (Lindmark and Bergquist, 2008). As such the regulatory system was based on performance rather than technology standards. The system furthermore stipulated a long-term perspective since the licenses had to be reassessed and renewed every 10 years on the basis of what was considered equal to the Best Available Technology (BAT) at the time the license was granted. As a general rule, the industrial polluters were required to take all precautionary measurers, and tolerate such restrictions on their activities as may be reasonably demanded.

The purpose of this requirement was to regulate with a view to technical practicality, the cost of pollution and pollution control measures and the socioeconomic benefits that accrued from the polluting activity. It is important to recognise that pollution control was designed not 
to jeopardise the competitiveness of the Swedish industry, but at the same time the objective of "preventing as far as possible additional pollution" had to be maintained. In practice the benchmark for what was considered 'possible' was BAT, i.e., what could be reasonably demanded was the adoption of the most efficient technology proved practicable in other industrial plants of the same type, either in Sweden or in other countries (Lundqvist, 1980). In specifying what could be reasonably demanded, the licensing authority was initially aided by a system of national emission guidelines. These guidelines were elaborated during the late 1960s by a joint panel of government-industry experts (Lundqvist, 1971), and they contained recommendations concerning the maximum allowable emissions of certain types of pollution from specified classes of stationary sources. The guidelines were legally binding only if specified in the conditions laid down in the license (Lundqvist, 1980).

The intense cooperation between the regulators and the polluters in establishing these guidelines was, according to Lundqvist (1997), an expression of a special style of Swedish environmental policy. A major vehicle for this regulatory approach was the view on information. Rational and balanced decisions could, it was perceived, only be reached if each party knew exactly what the other wanted and why (Lundqvist, 1971). This suggests therefore that an important objective of the system was to avoid significant information asymmetries concerning the availability and the costs of environmental technology. This approach, though, also built on limitations on public participation in the policy process; citizen groups were thus not represented in the elaboration of emission guidelines (Lundqvist, 1980). Until the 1990s, the Swedish industrial pollution regulation only involved a few networks of target groups.

Within this 'regulatory network' the semi-governmental Institute for Water and Air Protection (IVL) (and its service company) played an important role as a generator and intermeddler of technical knowledge and R\&D. The most central functions of IVL in the 1960s to the 1980s were related to the mobilization of resources (i.e., through pooled resources, the risks of any misguided investments in terms of knowledge development were dispersed), knowledge development, knowledge diffusion, and guidance of the search activities, all within a protected environment "in between" government and industry (Bergquist and Söderholm, 2012). The consensus among state and industry representatives on the value of IVL created a protected space, and legitimacy, for the knowledge and technology developed there. IVL further played a role as a fruitful arena for cross-pollination of knowledge. Here, the different organizations involved in the industrial environmental adaptation could exchange and thus refine information; this is where $\mathrm{R}$ (in $\mathrm{R} \& \mathrm{D}$ ) met with $\mathrm{D}$, where different lines of business met with each other, where technology producers met technology users and, not the least, where industry and R\&D met government. From the perspective of the regulatory authorities the activities of IVL assisted in: (a) preventing the build-up of significant firmregulator information asymmetries; and (b) developing the knowledge needed to comply with technology-forcing standards.

In brief, the Swedish environmental regulatory system was characterised by a high degree of centralisation, limited public participation, and a policy style seeking long-term cooperation and consensus between the regulator and the polluters (Lundqvist, 1980, 1997). For the above reasons Swedish firms are believed to having perceived the early environmental regulatory system as serious and stringent, but at the same flexible (Reinstaller, 2008). As will be stressed below, these features of the system also induced the diffusion of internal process changes designed to reduce emissions in favour of end-of-pipe solutions. 


\subsection{A Brief International Outlook on Environmental Regulation Systems}

The analysis in this paper has illustrated that regulatory approaches to industrial pollution typically go beyond identifying individual policy instruments and strategies; in practice the entire set up of the regulatory system (including informal norms, knowledge accumulation and transfer etc.) is decisive for the outcomes of environmental policies. This is confirmed in Jänicke (1992) who surveys the environmental policy frameworks in a number of countries. He demonstrates that the degree of success, measured in terms of the reduction of key emissions, varied considerably between the investigated countries, and these differences could not be attributed to the formal institutional set-up per se. Jänicke (1992) suggests that the presence of negotiated policies in some countries such as Sweden, often referred to as neocorporativism, has been essential for balancing new and old interests and has facilitated the environmental transformation of the economy. ${ }^{8}$ Long-term collaborative interaction among the concerned parties can make use of decentralized knowledge, manage adjustments in patterns of social behavior and legitimacy of policy outcomes (see also Lafferty and Meadowcroft, 1996). The most successful countries were in fact those in which a broader societal environmental concern was mobilized and integrated into the process of environmental adaptation. Meadowcroft (1997) develops this idea and also stresses the importance of encouraging, for instance, non-partisan public commissions, independent 'think-tanks', and NGO-sponsored research bodies to prepare their own forecasts, scenarios and visions.

In contrast, more conflict ridden general frameworks, opening up for regulatory capture, tend to produce poorer results in terms of reduced industrial emissions. Comparative studies have argued that the U.S. environmental regulatory approach was largely adversarial while most European countries were consensual (Brickman et al., 1985; Kelman, 1981; Lundqvist, 1980; O'Riordan, 1985; Vogel, 1995). In the USA, therefore, conflicting interests on a specific environmental issue have mostly been settled through litigation between parties representing different special interests while public authorities refrain as much as possible from interfering directly into what is viewed as a market process (Reinstaller, 2008). The drawback of this approach has been high U.S. litigation costs through a majority of regulatory issues ending up in court. The flip-side of this coin is that the transparency of the U.S. system has been - and may still be - higher than in Europe. Still, as proposed by Löfstedt and Vogel (2001), the U.S. type of adversarial regulatory regimes can lead to greater public distrust and may also be cost-ineffective. ${ }^{9}$

The differences between the Swedish and the North American systems concern also the specific designs of pollution control policies. The Swedish strategy of gradually imposing stricter regulations on the industry with each successive licensing process differs from the North American approach in which the primary paradigm for pollution control policies has comprised uniform technology-based guidelines for comparable plants (Harrison, 2002). This

\footnotetext{
${ }^{8}$ According to Katzenstein (1985) neo-corporativism is most clearly seen in smaller countries. Frequently quoted examples include Austria, the Netherlands, Sweden, Denmark and Japan.

${ }^{9}$ Distrust may however be a problem also in the negotiating types of systems found in several European countries. The practice of having regulators work with industry and the public is only effective if the regulators advance the public's best interest (Löfstedt and Vogel, 2001). In other words, distrust will emerge if the public believes that the regulatory process has been captured by either government, scientific, environmental or industry interest groups.
} 
made the U.S. and Canadian systems less cost-effective in that it denied firms some flexibility to experiment with different compliance measures (e.g., Lindmark and Bergquist, 2008). In addition, the North American systems also relied on air and water quality standards, allowing certain concentration of pollution in the surrounding air and water with respect to health aspects. The Swedish system has instead regulated the total emissions allowed from individual plants with respect to both health concerns and the ecological environment.

There appear to be subtle but nevertheless important differences also among the Nordic countries. Notably, although the Swedish and Finnish regulatory approaches exhibited many similarities over the relevant time period, i.e., case-by-case permitting system, gradually tightened emission limits, probation periods allowing search activities etc., they may have had different impacts on innovation activities and technology diffusion in the industrial sector (Similä, 2002; Söderholm and Bergquist, 2012). The Finnish case displays a coercive impact that is stronger with respect to the diffusion end-of-pipe technology than in process technology. This Similä (2002) explains by noting that specific end-of-pipe technologies more easily than process technology can be classified as BAT. The stronger focus on processinternal changes in the Swedish case was in part facilitated by the direct involvement of state authorities in industry-wide R\&D projects (Söderholm and Bergquist, 2012). This involvement constituted a necessary tool for Swedish authorities in the ambition to favor internal process changes designed to reduce emissions. Although there are some parallels to this in the Finnish case, as informed by Kivimaa and Mickwitz (2004), they primarily observe potential synergies between public R\&D support and environmental policy. ${ }^{10}$

\section{The Environmental Adaptation of a Swedish 'Hot-spot' Metal Smelter}

The Rönnskär metal smelter has a history of being the biggest Swedish hot spot for emissions of several pollutants such as sulphur dioxide, arsenic, cadmium, mercury, lead and copper. At the present, though, emissions from the smelter count only for a fraction of those measured in the 1970s. Figures 3-4 display the environmental performance of this smelter over the time period 1970-2002. Over this period the emissions of sulphur dioxide decreased by 90 percent while the discharges of a number of heavy metals were lowered by as much as 99 percent. At the same time, the smelter output more than doubled. Initially the Rönnskär smelter was concentrated to the production of gold and copper, but later also lead, silver, arsenic, zinc clinker as well as sulphur acid, selenium and nickel sulphate. The Rönnskär smelter represents the most thoroughly regulated industrial plant within the Swedish legal system of environmental protection. As late as in 1998 the smelter got a clean bill from the authorities. The complexity as well as the scope of pollutants discharged from the production processes implied a significant challenge for the company and for the public authorities during the 1970s and 1980s.

\footnotetext{
${ }^{10}$ Mickwitz et al. (2008) also report evidence from case studies in Finland suggesting that performance standards can have significant effects on inducing innovation, especially if the standards permit flexibility and are wellanticipated.
} 


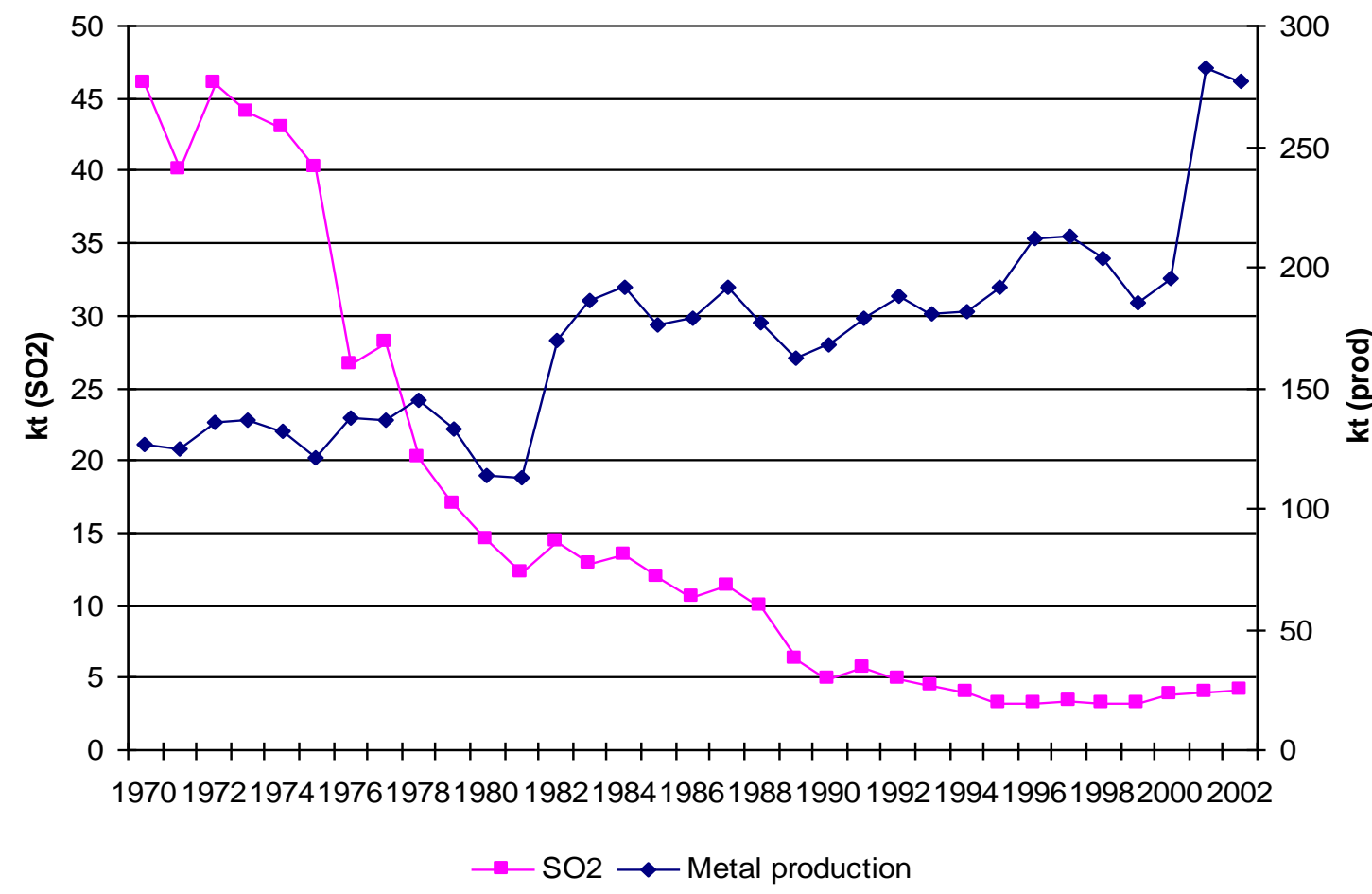

Figure 3: Sulphur Dioxide Emissions and Production at the Rönnskär Smelter, 1970-2002 Source: Bergquist (2007).

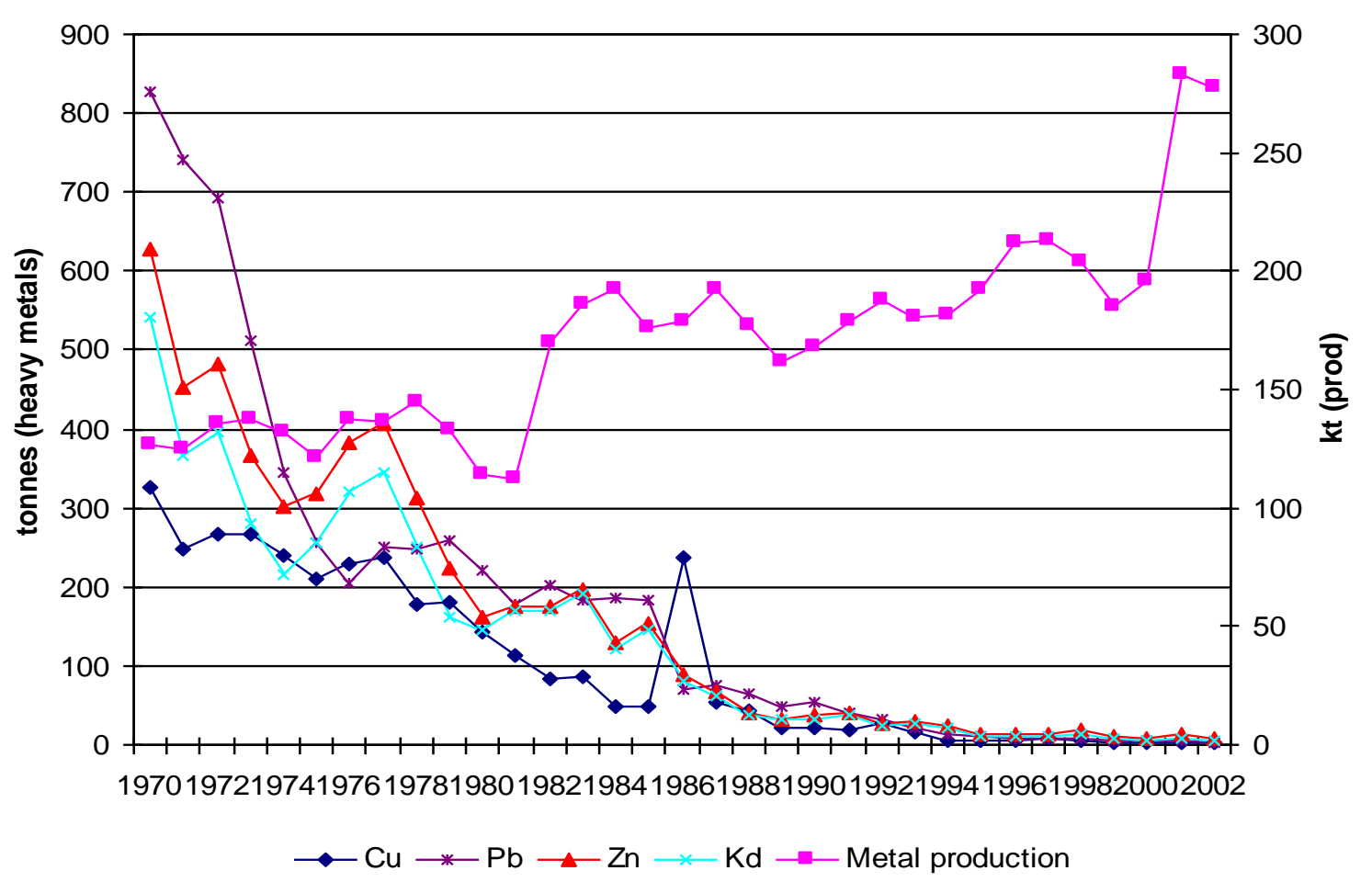

Figure 4: Emissions of Heavy Metals and Production at the Rönnskär Smelter, 1970-2002 Source: Bergquist (2007). 


\subsection{The Rönnskär Challenge}

In 1973 Boliden, the owner of the Rönnskär smelter, announced its plans to expand the production at the smelter, and with the new Environmental Protection Act the company was obligated to apply for a new license at the FBEP. Prior to the preliminaries for the licensing trial in 1973, neither the company nor the authorities had complete knowledge about the scope of the discharges from the smelter. Boliden therefore conducted an intensive survey work and only when this first comprehensive analysis of the total discharges from the plant had been completed, the authorities could acknowledge the critical ecological situation. It was recognized that the emissions of heavy metals and arsenic from the Rönnskär smelter were significant enough to affect a very large area, and even the overall content of arsenic in the entire Baltic Sea. The authorities therefore concluded that far-reaching emission cuts had to be implemented in order to avoid a future ecological disaster.

There was considerable uncertainty about how the emissions of arsenic, cadmium and lead affected different parts of the ecosystems. On top of that, the smelter was in a class by it self in terms of sulphur dioxide emissions emitting more than 40000 tons annually in the early 1970s (Figure 3). The company's application to the FBEP in 1973 therefore marked the start for an extensive period of licensing processes, a period which ended in 1986. The major reasons for the drawn-out licensing process were the considerable uncertainties about the ecological impacts of the discharges as well as about the pollution-reduction measures that could be perceived both technically and economically feasible. In this regulatory endeavour the generation and transfer of knowledge and information became important for all parts involved.

An intensive period of search activities was initiated in the early 1970s, both in terms of environmental impact assessments and of identifying BAT. Compared to the case of the Swedish pulp and paper industry (see section 5), which constituted a large number of domestic mills at the beginning of the 1970s, the Rönnskär smelter was the only one of its kind in Sweden. The remainder of this section discusses how the regulatory system facilitated the company's search activities and made possible the introduction of both existing and new process-internal environmental technologies.

\subsection{Environmental Regulation in Action: Licensing the Rönnskär Plant}

With the advent of the Environmental Protection Act in 1969, the FBEP had to stipulate the conditions under which the Rönnskär plant could operate. Before the FBEP decided on a final license, a negotiation between the company, the environmental authorities and other relevant stakeholders and experts took place. The basis for these negotiations was a plea that had been prepared by the company; it included detailed suggestions of how the company intended to improve its environmental standards, including the scope of the emission cuts. The plea also comprised a general description of the industrial processes, information about the competitive position of the company and about the ecological impacts of the industrial activities.

In the Rönnskär case negotiations in front of the FBEP took place in the years 1974, 1981, 1986, and 1998. At these negotiations different government authorities such as the Swedish Environmental Protection Agency (SEPA), the County Administrative Board, the National Board of Health, the Fishery Agency and the Public Health Committee (a local authority), among others, were asked to express their opinions on the plea, including calls for 
additional measures or clarifications. Environmental non-governmental organisations were also sometimes permitted to voice their concerns at the negotiations, but this was not common. This implies thus that the regulated company played a significant role in the design of the final license permit, but it was simultaneously influenced in the interplay with the different authorities and their experts. The license permit was therefore ultimately set in an interaction between demands from the authorities, the company's needs and the knowledge advanced jointly in the licensing process.

The licensing process for Rönnskär was divided into three stages (i.e., 1975-1980, 19811986, 1986-1994), in turn based on three major decisions stipulated by the Swedish government in 1975 and the FBEP in 1981 and 1986, respectively. Each stage contained a stipulated program of environmental adjustments were demands for emission cuts were incrementally tightened (Bergquist, 2007). At the same time, the company was obligated by the license to arrange an extensive investigation program on existing and future ecological impacts of the emissions in order to conclude on ecologically motivated emission cuts.

While the recipient investigations were mainly conducted by research organisations (e.g., IVL, university researchers etc.) at the firm's expenses, the efforts involved in identifying technical solutions were conducted by the company, and in part also in collaboration with the authorities (see below). The conditions stipulated in the license granted in 1975 were farreaching, but did still only represent a first modest step in the environmental adaptation process. The scope of the complexities and the integration of production processes made it difficult for the company and the authorities to identify timely technical solutions. It was clear that the lack of 'off-the-shelf' technologies in combination with the ecological hazards called for the implementation of so-called technology-forcing regulations.

In 1974 a specially assigned group from SEPA and Boliden was commissioned by the FPEB to visit a number of metal smelters and environmental authorities in the U.S. and Canada. The main objective of these travels was to identify reference plants and technically feasible pollution abatement measures. However, the environmental performance of the North American smelters were typically even poorer than that of the Rönnskär plant (SEPA, 1974), and for this reason technology transfers would not solve the problems faced. Instead the company's engineers were granted the flexibility to select, develop and test new technology suitable for its production processes as long as emissions could be kept below the levels that were stipulated in the license. These efforts proved productive. For instance, after intensive experimental work between 1975 and 1979, an integrated waste water purification facility was invented by the company's engineers (Bergquist, 2007). The regulatory system did therefore provide scope for creative solutions, and as a consequence of meeting the environmental demands of the 1970s, Boliden became a world leader in mercury and arsenic abatement technology as well as in the abatement of heavy metals from water (Solbu, 1986).

Nevertheless, the environmental and technical challenges associated with the Rönnskär case made the FBEP submit the case to the Swedish government in 1975. Consensus was reached that the uncertainties related to environmental damages as well as feasible measures were significant, and for this reason the 1975 license stipulated conditions for a five-year period. The company was granted a respite to carry out extensive environmental investments and to elaborate a strategy for even more radical emission cuts in the future. In implementing the investment program the company had to consult the authorities (most notably SEPA and the County Administrative Board) in 'joint consultations' (samråd). These permitted the com- 
pany to communicate eligible solutions as well as any problems faced, and the consultations made it possible for the authorities to control and remain well-informed about the progress of the company (both in terms of emission reductions and economic performance). These consultations were however characterized by substantial flexibility granted to the company executives in terms of developing and testing compliance strategies. When new knowledge was advanced in a technical project, the company was free to alter technical strategies to obtain emissions cuts if they proved effective. In this sense, the Swedish regulatory system relied on performance rather than technology standards, the latter typically used in the North America (e.g., in the U.S. Clear Water Act).

In 1981 the FBEP decided to grant the company an additional five-year respite period before the final license was set. The reason was that significant uncertainties concerning how far the company could go in terms of emission reductions remained and the ecological risks following the industrial activities at the plant were also poorly understood. Additional programs of recipient investigations were also imposed on the company; in the mid-1980s these represented the most extended and qualified examinations in Sweden with respect to the environmental impacts from one single industrial plant. Thus, new knowledge concerning both the abatement costs as well as the environmental damage costs had to be developed before the FBEP could decide on the final license conditions. There was therefore clear evidence of a shared uncertainty among regulators and the firm, and in essence the marginal abatement cost curve was jointly 'discovered' during the licensing process.

The knowledge generated could easily be appropriated by the company, SEPA, the County Administrative Board, the involved research institutions (e.g., IVL) and ultimately the FBEP. This was facilitated by the fact that both SEPA and the FBEP hosted substantial engineering expertise. Still, in contrast to the pulp and paper case (see section 5), the FBEP could not make use of reference plants in the domestic industry. In 1983 additional study trips to Germany and the UK were therefore undertaken jointly by the company, the County Administrative Board and the FBEP, and this was repeated in 1986 (prior to the final license trial) when the same group visited plants in Japan, the U.S., Canada and Belgium. An important conclusion from the latter visits was that the Japanese regulations were generally the most stringent, especially concerning the emissions of sulphur dioxide.

When the final license trial was held in 1986, SEPA referred to the Japanese standards in the case of sulphur dioxide. The Japanese reference plant essentially faced an emission constraint that was consistent with BAT, in this case the so-called flash smelting technology. The FBEP stated that in the Rönnskär case it would be "preferable" if Boliden could invest in a new flash smelting plant, but the company was granted the flexibility to identify and select other compliance measures. In the license decision the Board concluded:

"The central stipulations should [...] refer to the maximum emission levels to air and water from the entire business activity. In this the company is a given a possibility to, for instance, choose between installations of new process equipments or to retain existing equipment with additional purification works, or between more or less 'troublesome' raw materials, or between more or less far-reaching processes (reprocessing particulates etc.). [...] The central stipulations should be valid only after such a period during which the company has been given a reasonable respite to project and install the process- and purification equipments that are necessary to comply with the stipulations as well as the opportunity to 
allocate the relevant investments during a number of years." (authors' translation, emphasis in original). ${ }^{11}$

The FBEP defined clear time schedules for emissions reductions, e.g., the annual emissions of sulphur dioxide would not exceed the target values of 10000 and 5000 tonnes in the periods 1987-1989 and 1992-1993, respectively (compared to 45000 tonnes in 1970) and similar targets were imposed for particulates, lead, arsenic copper etc. Nevertheless, the history of the environmental adaptation of the Rönnskär plant also illustrates the regulator's use of extended compliance periods as an important policy tool. By allowing longer compliance periods, thus reducing investment uncertainty and permitting flexibility in compliance strategies, all parties involved can accept the increased uncertainty of setting a more ambitious technology-forcing performance standard.

Interestingly Boliden did not choose to invest in a new flash smelting process since the economic risks of such an investment were perceived too large. Instead the company made several structural process alterations and rationalisations that enabled both improved productivity and emissions reductions at lower costs than those associated with a new smelting unit (Bergquist, 2007). The emphasis on internal process solutions to promote pollution prevention also contrasts to the situation in the U.S. and Canada where end-of-pipe treatments have been prevalent. $^{12}$

\subsection{Summarizing Remarks}

The Rönnskär licensing case shows that the former Swedish regulatory approach to industrial pollution control had many of the attributes characterizing a dynamically efficient commandand-control policy. The authorities did not stipulate certain abatement measures, but granted the company substantial flexibility in identifying the most efficient compliance measures. Due to the cooperative approach of sharing information, new knowledge was advanced jointly and incrementally in close interaction between the company, the environmental authorities and the research institutions before the final license was issued.

Moreover, in the absence of clear-cut ambient environmental standards the FBEP had the opportunity to alter the regulatory demands on the company as new knowledge was advanced. This typically took place when the licenses were updated, and in the Rönnskär case demands were tightened continuously during the period 1975-1998. Interestingly, the company's own R\&D efforts enabled a move of the frontier to what was considered technically and economically feasible. In this way the regulatory system provided scope for creative solutions, private $\mathrm{R} \& \mathrm{D}$, and also enabled the company to coordinate pollution prevention measures with productive investments. Without an element of cooperation, flexible compliance periods and case-by-case considerations, this coordination would likely have had difficulties to work in practice. For the Rönnskär plant the above implied that a host of hazardous emissions could be radically reduced while at the same time allowing plant output to double over the period.

\footnotetext{
${ }^{11}$ National Archives, the Franchise Board of Environmental Protection (FBEP), Dnr Ä 57/73, No. 192/86 Aktbil. 284., p. 132.

${ }^{12}$ According to Hartje and Lurie (1985) the share of end-of-pipe technologies in pollution control investment in the U.S. in the period 1973-1982 was between 76 and 81 percent.
} 


\section{The Environmental Adaptation of the Swedish Pulp and Paper Industry}

\subsection{Environmental Challenges and Cooperation in the Pulp and Paper Industry}

The Swedish pulp and paper industry (PPI) has been important for the Swedish economy, and in contrast to the metal smelter case a large of number mills have operated in the country. Already in the early $20^{\text {th }}$ century the PPI faced public opposition due to its emissions into air and water, thus long before the advent of modern environmental regulation (e.g., Lundgren, 1974, Söderholm, 2009). As a result of this, the Swedish PPI developed a long-standing cooperative tradition in environmental $R \& D$ involving comprehensive inter-firm and statefirm interaction. Extensive inter-firm cooperation began already in the early 20th century, thus implying that this sector probably was better prepared than any other sector when the need for radically improved environmental standards increased during the 1960s and onwards.

An important component of this cooperative tradition was an early agreement among mills that process-integrated changes in the technology were necessary to combine output expansions and pollution reductions (Söderholm and Bergquist, 2012). At the time of the implementation of the Environmental Protection Act the share of environmental investments out of total investment was already high (about 10-14 percent) in the Swedish PPI (Söderholm and Bergquist, 2012). The PPI had joined up with research institutions and equipment suppliers to cooperate in large industry-wide $\mathrm{R} \& \mathrm{D}$ projects on environment protection under the coordination of the Forest industry's air and water protection research foundation (SSVL). Two to three large SSVL-projects per decade (focusing foremost on internal process changes) were carried out during the 1970-1990 period. Government authorities were also represented in the work, and they contributed with significant funding (15-40 percent of the total) (Bergquist and Söderholm, 2010a). For this reason the knowledge generated in the SSVL projects could also easily be appropriated by the regulators.

As was noted above, the IVL research institute also played an important role in the Swedish environmental adaptation process. It had a particularly large interest in the PPI, and was therefore often represented in the SSVL-projects. The strong regulator-firm collaboration was facilitated by the fact that SEPA was represented in both the IVL board and in the IVL research council. It thus had direct access to the development work that took place at both IVL and within the SSVL-projects (Bergquist and Söderholm, 2012). SEPA also had its' own research department (with laboratories) during the 1970s and 1980s, and the Agency hosted a number of significant R\&D projects during this period (e.g., one on the impacts of chlorine organic substance pollution in the PPI). A number of SEPA officials specialized on the PPI and studied the reports of SSVL and IVL thoroughly, as well as visited the mills and by that gained knowledge that was of significant value for the licensing processes. "We knew what we were talking about, we really could discuss process-related questions with the industry, we were respected by company representatives and they really could not get away with misleading information." 13 SEPA officials even functioned as 'prosecutors' at FBEP trials.

\footnotetext{
${ }^{13}$ Personal interview with a SEPA official with experiences of pulp and paper licensing processes during the 1980s, Stockholm, $9^{\text {th }}$ of June, 2010.
} 


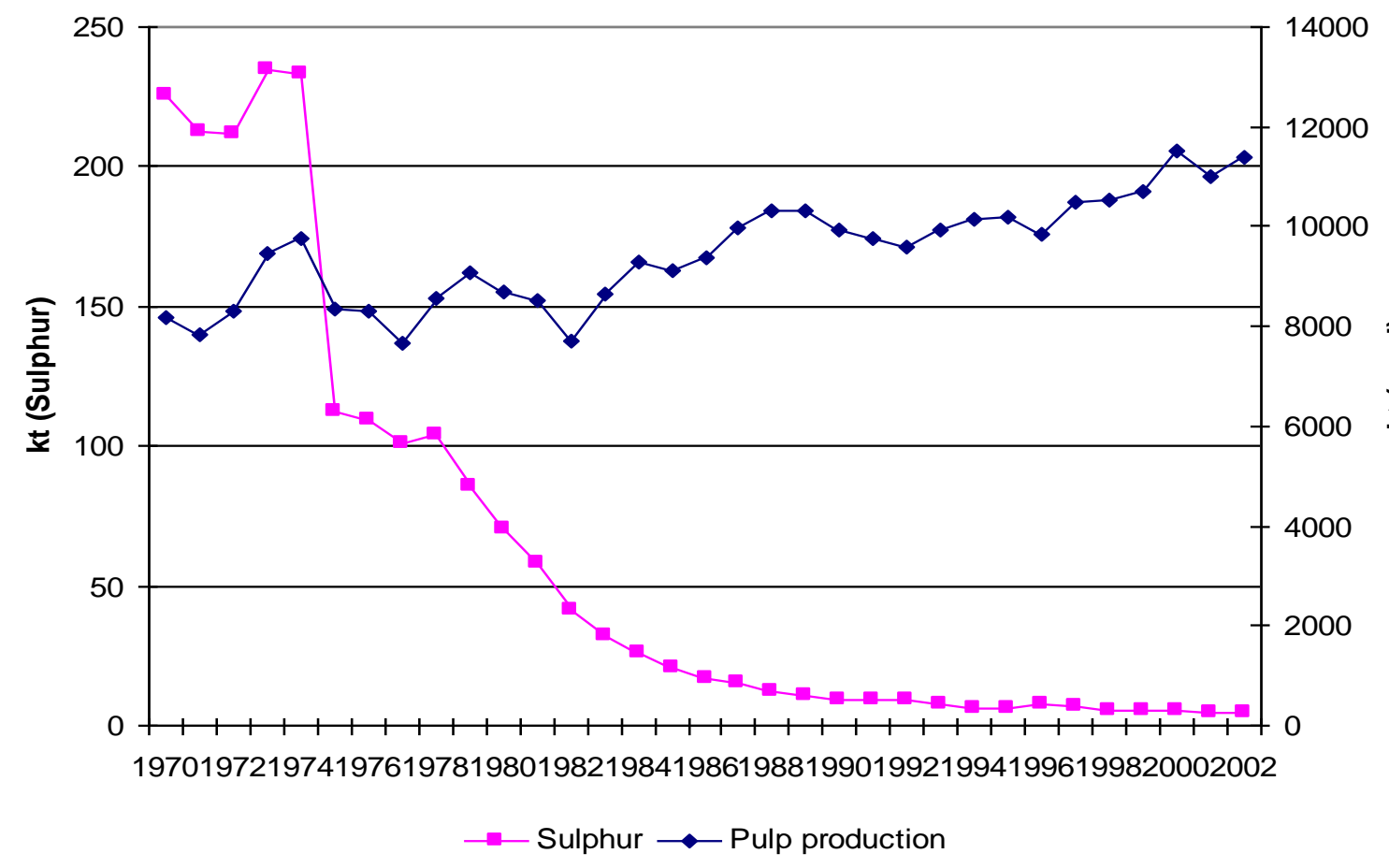

Figure 5: Sulphur Emissions and Pulp Production in Sweden, 1970-2002

Sources: Kindbom et al. (1993) and The Forest Industries Environmental Database (http://miljodatabas.skogsindustrierna.org/si/main/main.aspx?11=home)

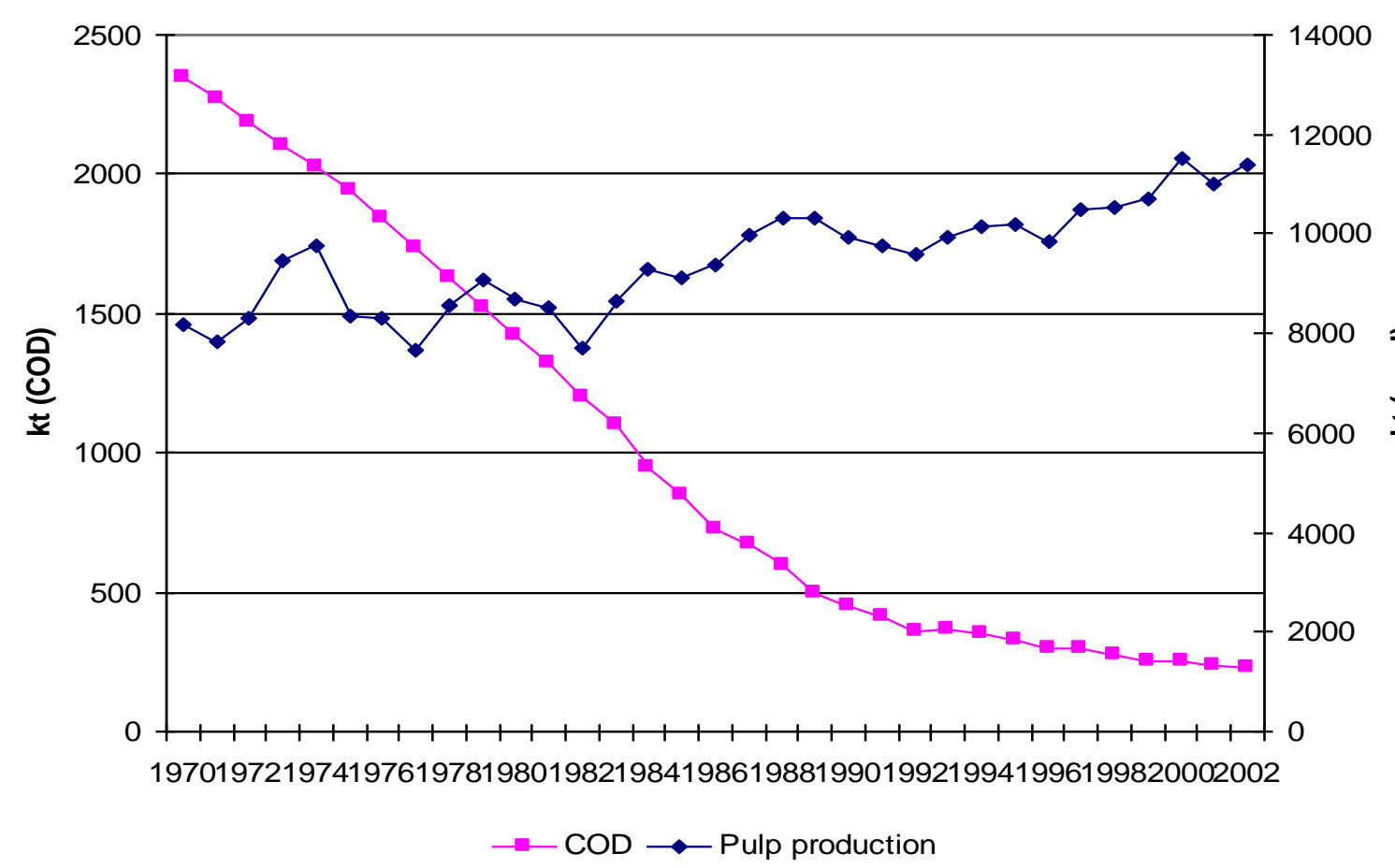

Figure 6: COD Emissions and Pulp Production in Sweden, 1970-2002

Source: The Forest Industries Environmental Database

(http://miljodatabas.skogsindustrierna.org/si/main/main.aspx?11=home) 
The above provides a picture of an active 'green' innovation system embracing the Swedish PPI, but similar to the Rönnskär case the emission reductions anticipated by the regulators in the case of, for instance, sulphur and COD (chemical oxygen demand), were significant and could generally not be addressed by employing only existing 'off-the-shelf' technology. In the remainder of this section we illustrate how pulp and paper mills and regulators coped with this challenge by focusing on the licensing of several mills between 1969 and $1992 .{ }^{14}$ As in the Rönnskär case we argue that the flexibility in compliance strategies combined with extended compliance (and probation) periods permitted an efficient and partly innovationinducing environmental transition in the Swedish PPI. Moreover, the cooperative tradition of sharing information between different mills as well as between the PPI and the authorities made the process effective. Figures 5-6 display that since the 1970s the emissions of sulphur and COD have been radically reduced, while at the same time the production of pulp has increased by almost 50 percent.

\subsection{Environmental Regulation in Action: Licensing Swedish Pulp and Paper Mills}

The experiences of pulp and paper licensing processes taking place under the FBEP during the 1970s show that the mills were provided with substantial flexibility in selecting efficient compliance strategies. Notably, in a couple of cases, even though SEPA had plead for the implementation of specific external purification methods, the FBEP gave the mills the right to choose between, or to investigate, different abatement technologies over a probation period in order to reach the imposed reduction targets. The FBEP would even explicitly emphasize how these investigations should not "in advance get tied to a certain result but should comprise the technical possibilities and costs for different alternative reduction levels." 15 In these cases the FBEP would not decide upon the final conditions of the license before the firms had completed its investigation and had suggested efficient methods. As in the Rönnskär case, investigations were often stipulated to be made in close consultation with SEPA and/or the County Administrative Board.

In contrast to the Rönnskär process, though, the individual pulp and paper mills also had access to an industry-wide network of environmental research activities. IVL, in particular, often played an important role in the licensing process. For instance, after one sulphate pulp mill had been requested in 1970/71 by the FBEP to investigate the chemical precipitation method, ${ }^{16}$ the mill engaged IVL, which launched a research project (Söderholm, 2005). A couple of years later SEPA requested an investigation of the chemical precipitation method in another pulp and paper licensing process. In this case, though, the mill could reject the method as both expensive and uncertain with reference to the above-mentioned IVL project. In yet another case IVL was involved in investigating a technology for reducing discharges of chlorinated substances at a Norwegian mill. SEPA referred to these development activities in

\footnotetext{
${ }^{14}$ For more details on different PPI licensing processes taking place under the FBEP, see Kinneryd (2010) and Söderholm (2005).

15 This quote has been drawn from the documentation of the licensing of the Munksund mill 1972-73. See decision of 1972-11-07, p. 14, County Administrative Board Archive E6B:58, Luleå, Sweden.

${ }^{16}$ Chemical precipitation is a method of wastewater treatment. Wastewater treatment chemicals are added to form particles which settle and remove contaminants. The treated water is then decanted and appropriately disposed of or reused.
} 
the licensing process; a profound technical discussion took place during the negotiations in front of the FBEP. Through these discussions, the firm was able to defend a more long-term and economically justifiable investment.

There are also plenty of examples in which the government authorities (e.g., SEPA) called/arranged for increased cooperation in environmental R\&D. In the licensing process mills were normally permitted to investigate technological solutions over a certain probation period (often 2 years). Many of the problems faced at a specific mill were, though, often a concern also at other mills, and these could therefore be investigated in more depth in the industry-wide SSVL research projects. In order to coordinate these industry-wide and millspecific research efforts, mills were sometimes offered extended probation periods to better match the time schedule of ongoing SSVL projects. ${ }^{17}$

In the 1980s the references made to parallel state- and industry-funded R\&D projects were abundant in the pulp and paper licensing processes under the FBEP. During this decade, though, the emissions of chlorinated organic substances from the bleaching process became to dominate the R\&D activities and licensing processes in the industry. SEPA, IVL, and SSVL investigated the environmental effects of these discharges as well as different solutions to reduce them (Bergquist and Söderholm, 2010); the investigations and the resulting reports were heavily referred to by both all parties in the licensing processes of the 1980s. Also in these cases we find examples where the licensing conditions stipulated by the FBEP for specific mills were only temporary awaiting the results of relevant SSVL project. One example of this was the licensing of the Gruvön mill in 1981 where some of the final licensing conditions were laid down only after a SSVL project on environmentally benign production of bleached pulp had been completed. ${ }^{18}$ This project was also cited in several other licensing cases in the early 1980s. In 1986 SSVL launched a new R\&D project (Environment 90) in which, among other things, efforts were made to treat the chlorate with sulphur dioxide, and during the second half of the 1980s a number of mills were requested by SEPA to investigate this method further (it was still on pilot-scale).

In this way the authorities and the industry jointly 'discovered' the uncertain abatement cost curve for chlorinated organic substances, and enabled an effective transition towards deeper emission reductions without necessarily compromising the competitiveness of individual firms. In the chlorine case we see clear evidence of a technology-forcing policy. During the 1980s the chlorine issue was intensively debated both nationally and globally, and in 1986 the FBEP took a clear standpoint in the chlorine question.

This was made in connection to the licensing of the Norrsundet sulphate pulp mill, a process which lasted over the period 1981-1987. ${ }^{19}$ These negotiations were attended by an unusually high proportion of representatives from the sulphate pulp industry, several of which

\footnotetext{
17 The licensing of the Munksund mill during the period 1972-73 is an example of where SEPA promised to extend the probation period if the investigations did not generate "meaningful" results within the stipulated time period (Protocol 1973-05-25, p. 15, County Administrative Board Archive E6B:58, Luleå, Sweden). In this case the investigation concerned the problem of sulphur emissions from other sources than from the burning of oil, and the mill had a representative in an ongoing SSVL project on this issue.

${ }^{18}$ Protocol 1982-01-26, p. 25, National Archive of Arninge, F1:32-36, Sweden: Stockholm

${ }^{19}$ Protocol 1986-05-15, National Archive of Arninge, E1:817-819, Sweden: Stockholm.
} 
were in the midst of parallel licensing processes, Chlorine producers, consultants, equipment suppliers, research institutions and authorities, and several additional representatives from SEPA were also present. ${ }^{20}$ In late 1986, in delivering the final conditions of the licensing process for the mill, the FBEP stated:

"In the present case, as well as in cases concerning the activities of several other mills with similar production processes (including Mönsterås, Mörrum, Östrand, Korsnäs and Skutskär) that currently are, or recently have been, the subject of licensing processes under the Board, an extensive amount of information regarding the prospects - in terms of costs, technology, production quality, etc. - for reducing emissions of chlorinated organic matter discharged along with wastewater from the bleaching process, as well as the effects on organisms due to emissions of different types of waste water have been presented. This material partly consists of the findings of the sector project SSVL 85 on the chemical and biological characterization and the effects of the waste water after various bleaching and purification processes, partly of the results from investigations and tests at the individual mills and within [the SSVL project] on process- and purification procedures, and partly also of results from SEPA's study of biological effects in aquatic ecosystems [...]. Through these findings, the Board has come to the conclusion that wastewater from the bleaching process cause significant local damage to water-based organisms."

"The investigation results also make clear that significant progress has been made in recent years in terms of different measures to reduce the emissions of chlorinated organic matter, including increasing the share of chlorine dioxide in the first bleaching stage as well as through improved process equipment and process control." 21

The FBEP announced that it expected even more technological development on this matter, and it anticipated more research attention (e.g., in SSVL projects) on the issue of increased delignification in the cooking- and bleaching stages as well as on the possibilities to switch to other bleaching chemicals. In the documentation supporting the licensing conditions for Norrsundet the FBEP advocated a particular abatement technology; it emphasized though that this should not be stipulated in the final conditions as the firm had both the right and the duty to use other methods if any shortcomings could be proved with this particular technology and/or if more effective methods were developed. In this way the Board maintained the regulatory strategy to permit flexibility in compliance strategies, while at the same time requiring emissions to comply with the performance of state-of-the-art (BAT) technology.

In a licensing process during the late 1980s the final conditions (laid out in 1987) stipulated a maximum discharge level of $1.5 \mathrm{~kg}$ chlorine per tonnage of bleached sulphate pulp produced. This requirement was, however, based on a technology that was not yet developed. Still, the FBEP expected this to be adopted within a relatively short time, but the Board made it clear that if this would not happen (before 1992) the firm would be free to apply for a less strict standard (following a new licensing process). SEPA argued that the stipulated level was possible to reach through technology that was already to be implemented

\footnotetext{
${ }^{20}$ The negotiations took place only a few months after the U.S. Environmental Protection Agency had found dioxins in fish caught downstream a number of paper mills.

${ }^{21}$ Documentation from the licensing of the Norrsundet mill in 1981-1987 (Decision 1986-12-09, p. 44f, National Archive of Arninge, E1:817-819, Sweden: Stockholm.
} 
at some Swedish mills. The significant environmental damages following these discharges also, SEPA argued, called for quick action.

The new technology involved a combination of the oxygen bleaching method and an increased use of chlorine dioxide in bleaching, and SEPA's anticipation of a rapid technical progress proved correct. In the early 1990s the Swedish PPI had got well passed a discharge level of $1.5 \mathrm{~kg}$ of organic bound chlorine/tonnage, with quite a few plants even producing totally chlorine free (TCF) bleached pulp and the remaining mills producing so-called elementary chlorine free (ECF) bleached pulp. This development put Swedish pulp and paper mills in the forefront internationally (Reinstaller, 2008). It is probably fair to suggest that the flexibility provided by the Environmental Protection Act of 1969 and the ways in which the FBEP utilized this flexibility along with the extensive joint R\&D efforts on the chlorine issue, were central in explaining the quick adaptation to TCF- and ECF production in the country.

\subsection{Summarizing Remarks}

The experiences of the environmental regulation of the Swedish PPI during the period 19701990 confirm many of the findings from the Rönnskär licensing process. Specifically, we find that: (a) the regulations built heavily on performance standards thus granting substantial flexibility to mills in terms of selecting the appropriate compliance measures; and (b) joint public-private R\&D efforts to develop and improve abatement technologies. Unlike the Rönnskär case the Swedish PPI consisted of a large number of mills, and there was therefore considerable scope for the spillover of new knowledge across firms, something that was heavily encouraged and required by the authorities such as SEPA. The presence of significant firm-regulator information asymmetries is likely to have been relatively modest, and any new knowledge was effectively used by the authorities in connection to new licensing processes.

The flexibility of the Environmental Protection Act also empowered the FBEP to grant firms probation periods during which the pulp and paper mills were given the opportunity to develop and test new solutions. This was typically done in close cooperation with other firms, research organizations (e.g., IVL), consultants and suppliers within the realms of large SSVL projects. As in the Rönnskär case, the flexibility granted in terms of compliance strategies and periods provided scope for identifying solutions that were deemed to be attractive over the long-run, and it also enabled the companies to coordinate pollution abatement measures with productive investments. Some of the performance standards stipulated by the FBEP were genuinely technology-forcing in that they built on assessments of technologies not yet fully developed. This was evident in the chlorine question, and likely facilitated by the fact that this issue was publicly debated during the 1980s. A FBEP and SEPA official with direct experiences of pulp and paper licensing processes in the late 1980s, comments on these circumstances as follows:

"The Board listened eagerly to the results of the investigations made by both the authorities and the industry and if we could identify prospects for a certain technological development, we granted probation periods and stipulated [performance standards] based on expected technological development and thus in fact stipulated technological development."22

\footnotetext{
${ }^{22}$ Personal interview with Ulla-Britta Fahlénius, Swedish Environmental Protection Agency, Stockholm $9^{\text {th }}$ of June, 2010.
} 
Thus, new knowledge was advanced incrementally within the system in close interaction between authorities, and the industry, and industry-wide R\&D projects were often already in full swing or planned for as new technology were brought up by, for instance, SEPA in connection to individual licensing processes. Moreover, the use of probation periods also likely increased the regulatory system's legitimacy.

\section{Concluding Discussion}

This paper has addressed the environmental policy challenges involved in achieving deep emission reductions in competitive industrial sectors. Industrial pollution control has been and is still - heavily based on case-by-case assessments and the monitoring of emission levels and/or technology standards (Sorrell, 2002). In the paper we have provided a theoretical review of the circumstances under which performance standards (emission limits) can constitute an essential part of an efficient policy aiming at deep emissions reductions, and we then employed this simple theoretical framework to analyze the experiences of the regulation of industrial emission in Sweden during the period 1970-1990.

The empirical findings are encouraging in that they suggest that the Swedish regulatory approach comprised many key elements of an efficient policy-induced transition towards radically lower emissions in the industrial sector. In essence, our analysis underscores the conclusion of Kriström and Wibe (1992), i.e., that industrial pollution control in Sweden during the 1970s and the 1980s led to substantial environmental improvements at a low cost, and the two case studies contribute with a more in-depth a micro-level understanding of how the regulatory processes assisted in achieving this. In this concluding section we choose to highlight three overall findings that also appear to be consistent with reported findings of the combined qualitative and quantitative literature on the innovation effects of environmental policy instruments (Kemp and Pontoglio, 2011). On each point we also highlight some additional lessons from our Swedish case studies.

The first finding is that flexibility and firm discretion in identifying the most suitable pollution abatement technology are important prerequisites for efficient compliance and innovation outcomes. In Sweden the BAT-requirements were important, but the regulator consistently avoided technology standards in favour of performance standards. In selected cases these were essentially technology-forcing but combined with the use of probation periods firms also faced intertemporal flexibility, and were thus given the opportunity to experiment with different solutions before the final license was decided. This type of flexibility has not always formed part of other countries' regulatory approaches (e.g., Yarime, 2007; Lindmark and Bergquist, 2008). However, the Swedish approach of the 1970s and the 1980s was at the same time demanding in that it relied on high regulatory competence and intensive information-sharing between the involved parties. This implies that the extent of firm-regulator information asymmetries was relatively limited, and new knowledge, e.g., developed in research programs, was effectively used by the authorities in upcoming licensing processes. It may be noted that in the 1970s SEPA hosted an entire research department focusing solely on addressing pollution problems from process industries. During 2011 the same authority had only one full-time employee solely responsible for inspecting the entire pulp and paper industry in the country. 
Second, earlier studies emphasize that there is typically no simple, one-directional (stimulus-response) link between the regulator and the regulated firms, and compliance and innovation are typically affected by multiple policies (Kemp and Pontoglio, 2011). In the Swedish case studies we have illustrated how the cooperative approach of sharing information implied that new knowledge was advanced jointly and incrementally in close interaction between the company, the environmental authorities and the research institutions before the final license was issued. In the Swedish pulp and paper case jointly funded R\&D projects were often in full swing or planned for as new technology were brought up by, for instance, SEPA in connection to individual licensing processes. In this way research activities provided a direct catalyst to the policy process based on performance standards.

Third and finally, while the existing theoretical literature tends to conclude that taxes and tradable emission allowances are superior in promoting innovation, there is also evidence of CAC approaches promoting more radical innovations (e.g., Taylor et al., 2005). Our results are well in line with these latter results and they illustrate the favourable political economy of imposing a combination of technology-forcing performance standards and relatively long compliance periods. As such the regulatory approach provided scope for creative solutions, private $\mathrm{R} \& \mathrm{D}$, and also permitted the affected companies to coordinate pollution prevention measures with productive investments. This is not meant to imply, though, that the Swedish experiences constitute a generic benchmark for all types of environmental policy challenges. ${ }^{23}$ Still, it could provide lessons for contemporary regulatory efforts directed at large stationary industrial facilities in other countries, e.g., in developing countries where the emissions of hazardous pollutants from industrial plants are still high and where there is an urgent need to lower these to avoid severe damages from hazardous pollutants to the environment.

\footnotetext{
${ }^{23}$ For instance, the results may be of limited interest for the design of global climate policy. First, in the case of greenhouse gas emissions their potential damage is relatively insensitive to the rate of emissions at any particular time. These fairly constant benefits to abatement imply that the presence of uncertainty in abatement costs due to unpredictable innovation will favor a tax-based approach over a quantity-based approach (e.g., Pizer, 1999). Second, the emissions of greenhouse gases are uniformly mixed and stem from a huge set of stationary and nonstationary sources, thus implying that polluter-regulator information asymmetries are likely to be huge.
} 


\section{References}

Ashford, N. A., C. Ayers, and R. F. Stone (1985). "Using Regulation to Change the Market for Innovation," Harvard Environmental Law Review, Vol. 9, pp. 419-466.

Bergquist, A-K. (2007). Guld och Gröna Skogar? Miljöanpassningen av Rönnskärsverken 1960-2000, Umeå Studies in Economic History No. 36, Umeå University, Sweden.

Bergquist, A-K. and K. Söderholm (2010). Miljöforskning i statens och industrins tjänst. Institutet för Vatten och Luftvårdsforskning (IVL) 1960-tal till 1980-tal, Umeå Papers in Economic History, No. 40/2010, Umeå University.

Bergquist, A-K., and K. Söderholm (2012). "The Formation of a Green Innovation System in Swedish Industry 1960-1989,” Business History Review, Winter, pp. 677-698.

Boyd, D. R. (2003). Unnatural Law. Rethinking Canadian Environmental Protection Law and Policy, UBD Press, Vancouver.

Brickman, R., S. Jasanoff, and T. Ilgen (1985). Controlling Chemicals: The Politics of Regulation in Europe and the United States, Cornell University Press, Ithaca, New York.

Bruneau, J. F. (2004). “A Note on Permits, Standards and Technology Innovation,” Journal of Environmental Economics and Management, Vol. 48, pp. 1192-1199.

Copper, M. L., and W. E. Oates (1992). "Environmental Economics: A Survey," Journal of Economic Literature, Vol. 30, pp. 675-740.

Glachant, M. (1999). The Efficiency of Policy Instruments for Regulating Industrial Pollution: A Coasean Approach, Working Paper, CERNA, Ecole Nationale Supérieure des Mines de Paris, Paris.

Harrison, K. (2002). "Ideas and Environmental Standard-Setting: A Comparative Study of Regulation of the Pulp and Paper Industry," Governance: An International Journal of Policy, Administration and Institutions, Vol. 15, No. 1, pp. 65-96.

Hartje, V. J., and L. R. Lurie (1985). Research and Development Incentives for Pollution Control Technologies, International Institute for Environment and Society, Wissenschaftszentrum, Berlin.

Jaffe, A. B., S. R. Peterson, P. R. Portney, and R. N. Stavins (1995). "Environmental Regulation and Competitiveness of U.S. Manufacturing: What Does the Evidence Tell Us?” Journal of Economic Literature, Vol. XXXIII, March, pp. 132-163.

Jänicke, M. (1992). "Conditions for Environmental Policy Success: An International Comparison," The Environmentalist, Vol. 12, No. 1, pp. 47-58.

Kamien, M. J., and N. L. Schwartz (1982). Market Structure and Innovation, Cambridge University Press, New York.

Kaplow, L., and S. Shavell (2002). "On the Superiority of Corrective Taxes to Quantity Regulation," American Law and Economics Review, Vol. 4, No. 1, pp. 1-17.

Katzenstein, P. J. (1985). Small States in World Markets. Industrial Policy in Europe, Cornell University Press, Ithaca.

Kelman, S. (1981). Regulating America, Regulating Sweden: A Comparative Study of Occupational and Health Policy, MIT Press, Cambridge. 
Kemp, R. (1997). Environmental Policy and Technical Change: A Comparison of the Technological Impact of Policy Instruments, Edward Elgar, Cheltenham.

Kemp, R., and S. Pontoglio (2011). "The Innovation Effects of Environmental Policy Instruments - A Typical Case of the Blind Men and the Elephant," Ecological Economics, Vol. 72, pp. 28-36.

Kindbom, K., K. Sjöberg, och G. Lövblad (1993). Beräkning av ackumulerad syrabelastning. Delrapport 1: emissioner av svavel, kväve och alkaliskt stoft i Sverige 1900-1990, Institute for Water and Air Protection (IVL), Gothenburg.

Kinneryd, H. (2010). Så länge det är tekniskt möjligt, ekonomiskt rimligt och miljömässigt motiverat: en studie av det tidiga svenska miljöskyddssystemet med fokus på miljöteknisk utveckling inom svensk pappers- och massaindustri, Research Report, Luleå University of Technology, Sweden.

Kivimaa, P., and P. Mickwitz (2006). "The Challenge of Greening Technologies - Environmental Policy Integration in Finnish Technology Policies," Research Policy, Vol. 35, pp. 729-744.

Kolstad, C. D. (2000). Environmental Economics, Oxford University Press, New York.

Kriström, B., and S. Wibe (1992). En effektiv miljöpolitik, Appendix 6 to LU 92, Ministry of Finance, Stockholm.

Krysiak, F. C. (2008). "Prices vs. Quantities: The Effects on Technology Choice," Journal of Public Economics, Vol. 92, pp. 1275-1287.

Lafferty, W., and J. Meadowcroft (1996). Democracy and the Environment: Problems and Prospects, Edward Elgar, Cheltenham.

Lindmark, M., and A. K. Bergquist (2008). "Expansion for Pollution Reduction? Environmental Adaptation of a Swedish and a Canadian Smelter, 1960-2005," Business History, Vol. 50, No.4, pp. 530-546.

Löfstedt, R., and D. Vogel (2001). "The Changing Character of Regulation: A Comparison of Europe and the United States," Risk Analysis, Vol. 21, No. 3, pp. 399-405.

Lundgren, L. (1974). Vattenförorening. Debatten i Sverige 1890-1921, Bibliotheca historica Lundensis Nr. 30, Lund University, Lund, Sweden.

Lundgren, L. (1999). "Från miljöproblem till miljövård," In Teknik som kultur - Tekniska museet 75 år, Tekniska museets årsbok 1999, Höjeberg, M. (Ed.), Daedalus, Vol. 67.

Lundqvist, L. (1971). Miljövårdsförvaltning och politisk struktur, Verdandi, Uppsala.

Lundqvist, L. (1980). The Hare and the Tortoise: Clean Air Policies in the United States and Sweden, The University of Michigan Press, Ann Arbor.

Lundqvist, L. (1997). "Sweden,” In M. Jänicke and H. Weidner (Eds.), National Environmental Policies. A Comparative Study of Capacity Building, Springer, Berlin, pp. 45-71.

Meadowcroft, J. (1997). "Planning for Sustainable Development: Insights from the Literatures of Political Science," European Journal of Political Research, Vol. 31, pp. 427454.

Mendelsohn, R. (1984). "Endogenous Technical Change and Environmental Regulation," Journal of Environmental Economics and Management, Vol. 11, pp. 202-207. 
Mickwitz, P. (2003). "Is It as Bad as It Sounds or as Good as It Looks? Experiences of Finnish Water Discharge Limits,” Ecological Economics, Vol. 45, pp. 237-254.

Mickwitz, P., H. Hyvättinen, and P. Kivimaa (2008). "The Role of Policy Instruments in the Innovation and Diffusion of Environmentally Friendlier Technologies: Popular Claims versus Case Study Experiences," Journal of Cleaner Production, Vol. 16S1, pp. S162S170.

Milliman, S. R., and R. Prince (1989). "Firm Incentives to Promote Technical Change in Pollution Control," Journal of Environmental Economics and Management, Vol. 17, pp. 247-265.

Nentjes, A. (1988). "An Economic Model of Innovation in Pollution Control Technology," Paper presented at the Annual Meeting of the American Association of Environmental and Resource Economists, New York, 28-30 December.

Nentjes, A., F. P. de Vries, and D. Wiersma (2007). "Technology-forcing through Environmental Regulation," European Journal of Political Economy, Vol. 23, pp. 903-916.

O`Riordan, T. (1985). Approaches to Regulation," In H. Otway and M. Peltu (Eds.), Regulating Industrial Risks," Butterworths, Oxford, United Kingdom.

Pizer, W. A. (1999). "The Optimal Choice of Climate Change Policy in the Presence of Uncertainty," Resource and Energy Economics, Vol. 21, pp. 255-287.

Reinstaller, A. (2008). "The Technological Transition to Chlorine Free Pulp Bleaching Technologies: Lessons for Transition Policies," Journal of Cleaner Production, Vol. 16, No. 1, pp. 133-147.

Requate, T. (2005). "Dynamic Incentives by Environmental Policy Instruments - A Survey," Ecological Economics, Vol. 54, pp. 175-195.

Requate, T., and W. Unold (2003). "Environmental Policy Incentives to Adopt Advanced Abatement Technology: Will the True Ranking Please Stand Up," European Economic Review, Vol. 47, pp. 125-146.

Sandén, B., and C. Azar (2005). "Near-term Technology Policy for Long-term Climate Targets. Economy-wide versus Technology Specific Approaches," Energy Policy, Vol. 33, pp. $1557-1576$.

Sartorius, C., and S. Zundel (Eds.) (2005). Time Strategies, Innovation and Environmental Policy, Edward Elgar, Cheltenham.

Similä, J. (2002). "Pollution Regulation and Its Effects on Technological Innovations," Journal of Environmental Law, Vol. 14, No. 2, pp. 143-160.

Söderholm, K. (2005). Tekniken som problem och lösning: föroreningsmotstånd och teknikval i 1900-talets svenska pappersmassaindustri, Doctoral Dissertation 2005:34, History of Technology Unit, Luleå University of Technology, Sweden.

Söderholm, K. (2007). Miljöforskning inom den svenska pappers- och massaindustrin: från sekelskiftets luktkommitté till 60- och 70-talens laboratorier och forskningsinstitut, Research Report 2007:11, Luleå University of Technology Press. 
Söderholm, K. (2009). "Environmental Awakening in the Swedish Pulp and Paper Industry: Pollution Resistance and Firm Responses in the Early 20th Century," Business Strategy and the Environment, Vol. 18, No. 1, pp. 32-42.

Söderholm, K., and A-K. Bergquist (2012). "Firm-collaboration and Environmental Adaptation: The Case of the Swedish Pulp and Paper Industry 1900-1990," Scandinavian Economic History Review, Vol. 2, No. 60, pp. xx.

Söderholm, P., and A. Christiernsson (2008). "Policy Effectiveness and Acceptance in the Taxation of Environmentally Damaging Chemical Compounds," Environmental Science \& Policy, Vol. 11, No. 3, pp. 240-252.

Solbu, E. (1986). “Reningskrav på Rönnskär utvecklade ny miljöteknik,” Bergsmannen, Vol. 6, pp. 10-13.

Sorrell, S. (2002). "The Meaning of BATNEEC: Interpreting Excessive Costs in UK Industrial Regulation," Journal of Environmental Policy and Planning, Vol. 4, pp. 23-40.

Stavins, R. N. (1995). "Correlated Uncertainty and Policy Instrument Choice," Journal of Environmental Economics and Management, Vol. 30, pp. 218-232.

Swedish Environmental Protection Agency (SEPA) (1974). Report from a Study Tour to USA and Canada, Vol. F2GK:88, Stockholm.

Taylor, M. R., E. S. Rubin, and D. A. Hounshell (2005). "Control of $\mathrm{SO}_{2}$ Emissions from Power Plants: A Case of Induced Technological Innovation in the US," Technological Forecasting and Social Change, Vol. 72, pp. 697-718.

Viscusi, W. K., J. M. Vernon, and J. E. Harrington (2005). Economics of Regulation and Antitrust, $4^{\text {th }}$ edition, MIT Press, Cambridge.

Vogel, D. (1995). Trading Up: Consumer and Environmental Regulation in a Global Economy, Harvard University Press, Cambridge.

Weitzman, M. (1974). "Prices versus Quantities," Review of Economic Studies, Vol. 41, pp. 477-491.

Yarime, M. (2007). "Promoting Green Innovation or Prolonging the Existing Technology: Regulation and Technological Change in the Chlor-Alkali Industry in Japan and Europe," Journal of Industrial Ecology, Vol. 11, No. 4, pp. 117-139. 